\title{
PENGEMBANGAN KONTEN INTERAKTIF MATA PELAJARAN SIMULASI DAN KOMUNIKASI DIGITAL BERSTRATEGI BLENDED LEARNING DI KELAS X SMK NEGERI 3 SINGARAJA
}

\author{
I Gede Widiada Adi Braneva ${ }^{1}, \mathrm{P}$ Wayan Arta Suyasa ${ }^{2}$, I Nengah Eka Mertayasa ${ }^{3}$ \\ Program Studi Pendidikan Teknik Informatika \\ Jurusan Teknik Informatika \\ Fakultas Teknik dan Kejuruan \\ Universitas Pendidikan Ganesha

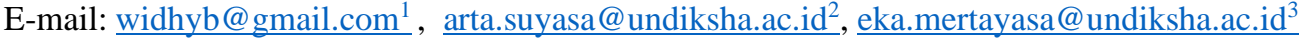

\begin{abstract}
Abstrak-Penyampaian materi mata pelajaran Sistem Komunikasi dan Digital masih menggunakan metode ceramah dan konten pembelajaran hanya berasal dari sumber bacaan statis seperti modul pembelajaran tanpa interaksi sehingga menimbulkan hambatan dalam proses pembelajaran. Penelitian ini bertujuan untuk menghasilkan dan mengimplementasikan serta mendeskripsikan respon guru dan siswa terhadap pengembangan konten interaktif mata pelajaran Simulasi dan Komunikasi Digital berstrategi blended learning di kelas X SMK Negeri 3 Singaraja. Metode yang digunakan dalam penelitian ini ialah research and development dengan model pengembangan ADDIE yaitu analyze, design, development, implementation dan evaluation. Subjek penelitian ialah 31 orang peserta didik kelas XI Multimedia di SMK Negeri 3 Singaraja. Berdasarkan tahapan yang telah dilalui, diperoleh sebuah produk konten pembelajaran interaktif menggunakan teknologi Articulate Storyline 3 berstrategi blended learning yang didistribusikan melalui LMS Google Classroom dengan perolehan koefisien rata-rata validitas ahli isi dan ahli media sebesar 1,00 berada pada kriteria "Sangat Valid". Untuk efektivitas produk mendapatkan perolehan N-Gain sebesar 0,91 dengan kriteria "Efektif". Selain itu, hasil rata-rata skor respon siswa dan guru adalah sebesar 68,9 dan 47 dengan kriteria "Sangat Positif".
\end{abstract}

Kata Kunci: Blended Learning, Konten Interaktif, Simulasi dan Komunikasi Digital

\begin{abstract}
Delivering Communication and Digital Systems subject still uses the lecture method and the learning content only comes from static reading sources such as learning modules without any interaction, this is causing obstacles in the learning process. This study aims to produce, implement and describe teacher and students' responses to the development of interactive content in Simulation and Digital Communication subjects with a blended learning strategy in class X SMK Negeri 3 Singaraja. The method used in this research is Research and Development (R\&D) with the ADDIE as the development model, namely analyze, design, development, implementation and evaluation. The subjects of this research were 31 students of class XI Multimedia at SMK Negeri 3 Singaraja. Based on the stages that have been passed, the interactive learning content product is using Articulate Storyline 3 technology with a blended learning strategy that is distributed through the LMS Google Classroom with the acquisition of the average coefficient of validity of content experts and media experts of 1.00 is in the "Very Valid" criteria. For the effectiveness of the product, the N-Gain obtained is 0.91 with the criteria of "Effective". In addition, the results of the average student and teacher response scores were 68.9 and 47 with the "Very Positive" criteria.
\end{abstract}

Keywords: Blended Learning, Interactive Content, Simulation and Digital Communication 


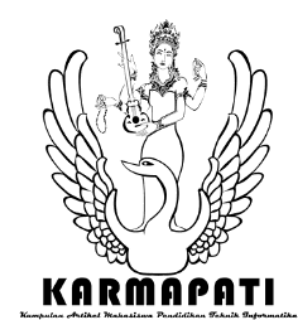

e-ISSN: 2685-7006 | p-ISSN: 2252-9063

Kumpulan Artikel Mahasiswa Pendidikan Teknik Informatika

(KARMAPATI)

Volume 10, Nomor 2, Tahun 2021

\section{PENDAHULUAN}

Perkembangan teknologi informasi terjadi begitu cepat, pada era revolusi industri 4.0 seperti saat ini, peranan teknologi di setiap bidang kehidupan sangatlah penting untuk mempermudah kegiatan yang dilakukan oleh manusia, termasuk di bidang pendidikan. Dunia pendidikan tidak bisa lepas dari proses belajar mengajar. Dalam proses belajar mengajar tentunya akan melibatkan interaksi antara siswa dan juga guru baik itu secara langsung (tatap muka) maupun secara tidak langsung (media pembelajaran). Peranan media pembelajaran dalam proses belajar mengajar dapat menentukan efektifitas penyampaian materi dan juga sebagai upaya tercapainya tujuan pembelajaran yang direncanakan. [1] menyatakan bahwa media adalah bagian yang tidak terpisahkan dari proses belajar mengajar demi tercapainya tujuan pendidikan pada umumnya dan tujuan pembelajaran di sekolah pada khususnya. Menurut [2] bahwa media pembelajaran dapat dipahami sebagai segala sesuatu yang dapat menyampaikan atau menyalurkan pesan dari sumber secara terencana, sehingga terjadi lingkungan belajar yang kondusif, dimana penerimanya dapat melakukan proses belajar secara efisien dan efektif. Media dengan konten pembelajaran yang baik dan menarik akan membantu guru untuk mengarahkan siswa dalam mencapai tujuan pembelajaran dan juga secara langsung dapat meningkatkan ketertarikan siswa dalam mempelajari serta menjelajah informasi dalam bentuk konten yang dikemas didistribusikan dalam bentuk media pembelajaran.

Guru dalam penyampaian materi di setiap mata pelajaran pasti akan membutuhkan media pembelajaran untuk penyampaian konten pembelajaran dan untuk menunjang proses pembelajaran, tidak terkecuali pada mata pelajaran Simulasi dan Komunikasi Digital. Mata pelajaran Simulasi dan Komunikasi Digital merupakan salah satu mata pelajaran produktif yang masuk kedalam bidang keahlian SMK (C1) multimedia yang ada di SMK Negeri 3 Singaraja. Pada mata pelajaran Simulasi dan Komunikasi Digital peserta didik diajarkan bagaimana menggali ide untuk memecahkan masalah terkait produk/layanan, mencari solusi alternatif, dan mengkomunikasikan dalam bentuk kolaborasi, sehingga mata pelajaran ini menjadi salah satu life skill dari peserta didik. Banyak kompetensi yang dapat dipelajari peserta didik dalam mata pelajaran ini, salah satunya adalah praproduksi dan produksi video, dimana ruang lingkup materi pokok yang termasuk di dalam pembahasan sangatlah kompleks dari pemahaman awal materi, konsep sampai dengan pengoperasian perangkat lunak. Karena keterbatasan waktu dan kompleksitas materi pelajaran yang harus diajarkan kepada siswa, sangat tepat dan sesuai jika bahan ajar dikemas dalam media digital, sehingga bahan ajar yang dibuat menjadi lebih sederhana, interaktif, menarik, dan mudah dipahami oleh siswa. Selain itu juga dapat memperlancar proses pembelajaran [3]. Oleh karena itu menjaga motivasi peserta didik dalam belajar dan mengemas materi atau konten pembelajaran secara menarik diharapkan dapat meningkatkan kualitas belajar dan hasil belajar yang dimiliki oleh peserta didik.

Dari hasil observasi dan wawancara yang dilakukan di SMK Negeri 3 Singaraja dengan Luh Putu Sri Pranata Ningsih, S.Pd selaku guru mata pelajaran Simulasi dan Komunikasi Digital kelas $\mathrm{X}$ berkaitan dengan sumber belajar yang digunakan, terdapat beberapa permasalahan yang berkaitan dengan proses belajar mengajar, seperti sulitnya siswa dalam memahami cakupan materi pembelajaran yang diberikan baik itu dalam bentuk konsep materi ataupun praktikum yang melibatkan keterampilan peserta didik, hal itu dikarenakan materi pembelajaran yang bersifat abstrak sehingga menyebabkan pemikiran siswa hanya menduga-duga mengenai istilah yang mungkin baru mereka temui. Permasalahan selanjutnya yaitu dalam kegiatan pembelajaran. Pemanfaatan konten pembelajaran atau pengemasan materi konten pembelajaran yang kurang bervariasi diberikan kepada peserta didik membuat berkurangnya motivasi dan gairah belajar peserta didik dalam memanfaatkan informasi yang diberikan secara mandiri. Dalam pencapaian hasil belajar yang maksimal, motivasi belajar sangatlah penting sebagai pengarah dan juga penggerak peserta didik dalam mencapai tujuan belajar. Permasalahan selanjutnya yang ditemukan adalah kegiatan pembelajaran yang berlangsung hanya bersifat satu arah yang lebih berpusat kepada guru dengan penyampaian materi menggunakan metode ceramah dan pemberian materi atau konten pembelajaran hanya berasal dari sumber bacaan statis seperti modul pembelajaran tanpa interaksi. Sesuai dengan permasalahan yang ditemukan, peranan teknologi di era digital seperti saat ini dapat membantu dalam penyelesaian masalah di bidang pendidikan. Dengan adanya teknologi informasi, proses pembelajaran tidak lagi terbatas oleh jarak dan juga waktu karena belajar mengajar dapat dilakukan dimana saja dan kapan saja melalui fasilitas perangkat digital dan juga internet. Salah satu strategi pembelajaran yang mendukung hal tersebut adalah pembelajaran blended learning. Strategi pembelajaran blended learning dirasa sesuai dan banyak diterapkan di dunia 


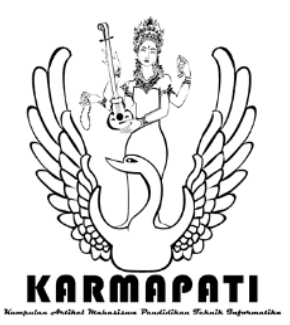

e-ISSN: 2685-7006 | p-ISSN: 2252-9063

Kumpulan Artikel Mahasiswa Pendidikan Teknik Informatika

(KARMAPATI)

Volume 10, Nomor 2, Tahun 2021

pendidikan karena dalam penerapannya bisa disesuaikan dengan sistem tatap muka baik itu secara langsung di sekolah ataupun tatap muka dengan virtual classroom melalui video conference dan juga sistem pembelajaran daring yang memanfaatkan Learning Management System (LMS) sebagai fasilitas yang menghubungkan antara guru dan peserta didik. [4] menyatakan bahwa blended learning merupakan pembelajaran yang mengkombinasikan antara pembelajaran online dengan face-to-face.

Pengembangan konten pembelajaran tidak terlepas dari teknologi yang digunakan, salah satu teknologi yang mendukung pengembangan konten pembelajaran adalah articulate storyline 3. Articulate storyline 3 merupakan perangkat lunak yang difungsikan sebagai media dalam melakukan presentasi atau menyampaikan informasi. Tentunya teknologi ini sudah terintegrasi langsung dengan HTML5 yang memungkinkan banyak pilihan platform dalam pendistribusian produk. Kelebihan dari perangkat lunak ini dibandingkan perangkat lunak sejenis seperti adobe flash adalah tidak dibutuhkannya bahasa pemrograman dalam proses pembuatannya. Dalam pemanfaatan konten pembelajaran tersebut, tentu saja peran guru akan lebih dikurangi dalam proses pembelajaran dan orientasi pembelajaran lebih terfokus kepada siswa.

Berdasarkan uraian yang telah dijelaskan tersebut, maka peneliti tertarik untuk mengembangkan konten interaktif dengan memanfaatkan kolaborasi antara teks, gambar, audio dan animasi menggunakan teknologi articulate storyline 3 dengan berstrategi pembelajaran blended learning dalam mata pelajaran Simulasi dan Komunikasi Digital pada materi praproduksi dan produksi video di SMK Negeri 3 Singaraja dengan penelitian yang berjudul "Pengembangan Konten Interaktif Mata Pelajaran Simulasi dan Komunikasi Digital Berstrategi Blended Learning Di Kelas X SMK Negeri 3 Singaraja."

\section{KAJIAN TEORI}

A. Media Pembelajaran

Jika dilihat secara etimologis, kata "media" berasal dari bahasa latin yaitu "medius" yang memiliki arti tengah, perantara ataupun pengantar. Kata media pada dasarnya mengarah pada sesuatu hal yang dapat dijadikan sebagai tempat, sarana ataupun alat untuk melakukan komunikasi. Namun secara garis besar, media merupakan segala hal dalam bentuk apapun yang dapat dijadikan sebagai perantara oleh seseorang dalam menyapaikan dan mengkomunikasikan ide, gagasan dan juga pendapat sehingga dari penyampaian dan komunikasi mengenai ide, gagasan dan pendapat tersebut dapat tersampaikan ke penerima atau seseorang yang ingin dituju [5]. Sejalan dengan pendapat tersebut, [6] menyatakan bahwa media merupakan suatu perantara dari pengirim pesan ke penerima pesan untuk menyalurkan informasi berupa pesan yang ingin disampaikan sehingga dapat menarik perhatian seseorang untuk memperhatikan pesan yang disampaikan.

\section{B. Konten Interaktif}

Menurut kamus besar bahasa Indonesia (KBBI) konten merupakan sebuah informasi yang terdapat pada sebuah media ataupun produk elektronik. Pengemasan konten dalam upaya penyampaiannya dapat dilakukan melalui berbagai macam perantara baik itu pengemasan konten secara statis ataupun secara dinamis. Konten dapat didistribusikan melalui berbagai macam media seperti yang sudah banyak tersedia pada saat ini seperti internet, televisi, radio dan lain sebagainya. Jika dikaitkan dengan kegiatan pembelajaran, Konten yang berupa materi pembelajaran merupakan salah satu komponen yang sangat penting dalam pelaksanaan kegiattan pembelajaran. Konten atau materi pembelajaran ini menyangkut tentang apa yang diajarkan dan apa yang harus dipahami peserta didik.

C. Pembelajaran Blended Learning

Blended learning secara etimologi terdiri dari dua kata, yaitu blended yang berarti kombinasi/campuran dan learning yang memiliki arti belajar. Blended learning merupakan pembelajaran yang mengkombinasikan dua sistem pembelajaran yaitu pembelajaran tatap muka atau sistem pembelajaran konvensional dan sistem pembelajaran yang memanfaatkan teknologi dalam komunikasi serta interaksinya yaitu sistem pembelajaran daring atau online. Menurut [7] pembelajaran blended learning merupakan pembelajaran dengan menggabungkan atau mengkombinasikan berbagai teknologi, salah satunya berbasis web untuk mencapai tujuan pendidikan..

D. Teori Belajar

Teori belajar pada dasarnya merupakan gabungan dari prinsip yang memiliki keterkaitan dan penjelasan dari sejumlah fakta yang berkaitan dengan kegiatan belajar. Teori belajar umumnya menjelaskan tentang bagaimana proses belajar itu terjadi pada setiap peserta didik atau individu yang dapat membantu guru dalam penyelenggaraan proses pembelajaran dengan baik, efisien dan juga efektif. Dalam pengembangan konten interaktif yang dilakukan penulis mengacu pada 3 teori 


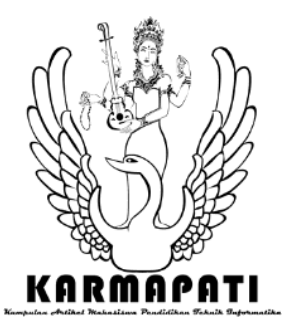

e-ISSN: 2685-7006 | p-ISSN: 2252-9063

Kumpulan Artikel Mahasiswa Pendidikan Teknik Informatika

(KARMAPATI)

Volume 10, Nomor 2, Tahun 2021

belajar, yaitu (1) teori belajar Konstruktivisme, (2) teori belajar Behavioristik dan (3) teori belajar Kognitifisme.

E. Learning Management Systems (LMS)

Learning Management System (LMS) merupakan pengelolaan proses pembelajaran dengan menggunakan teknologi yang digunakan sebagai sarana pendukung di dalam proses pembelajaran tersebut. Pembelajaran dengan menggunakan Learning management system merupakan suatu pendekatan dengan memanfaatkan penggunaan aplikasi komputer sebagai alat pendukung di dalam manajemen pembelajaran [8]. Definisi mengenai Learning Management System secara sederhana juga dijelaskan oleh [9] sebagai pengelolaan interaksi siswa dan guru di dalam proses pembelajaran berbasis teknologi melalui website. Selain itu Learning Management System atau istilah lainnya sebagai platform e-elarning merupakan suatu perangkat lunak yang berisikan berbagai layanan yang dapat membantu guru atau pendidik di dalam mengelola kegiatan pembelajaran [10].

F. Model Pengembangan ADDIE

Model pengembangan ADDIE merupakan model pengembangan desain pembelajaran yang berlandaskan pendekatan sistem yang efektif dan efisien serta memiliki proses yang interaktif, yaitu hasil evaluasi dari setiap tahapan dapat membawa pengembangan pembelajaran ke tahapan selanjutnya. Hasil akhir dari suatu tahap adalah produk awal bagi tahap selanjutnya. Menurut [11], menyatakan bahwa model pengembangan ADDIE terdiri atas lima tahapan, yaitu: (1) analisis (analyze), (2) perancangan (design), (3) pengembangan (development), (4) implementasi (implementation), dan yang terakhir (5) evaluasi (evaluation).

G. Karakteristik Mata Pelajaran Simulasi dan Komunikasi Digital

Mata Pelajaran Simulasi dan Komunikasi Digital merupakan salah satu mata pelajaran produktif kelas X yang masuk kedalam Bidang Keahlian SMK (C1) yang berkaitan erat dengan teknologi dan komunikasi sesuai dengan surat keputusan Direktorat jendral Pendidikan Dasar dan Menengah Nomor 130/D/KEP/KR/2017 tentang struktur kurikulum pendidikan menengah kejuruan. Pada Mata Pelajaran Simulasi dan Komunikasi Digital siswa diajarkan bagaimana menggali ide untuk memecahkan masalah terkait produk/layanan, mencari solusi alternatif, dan mengkomunikasikan dalam bentuk kolaborasi, sehingga mata pelajaran ini menjadi salah satu life skill dari siswa.

\section{METODE PENELITIAN}

A. Jenis Penelitian

Penelitian yang dilakukan peneliti merupakan jenis penelitian dan pengembangan atau Research and Development (R\&D). Menurut [12] Metode penelitian Research and Development (R\&D) digunakan untuk menghasilkan produk tertentu dan menguji keefektifan produk.

B. Model Pengembangan

Model pengembangan yang digunakan dalam pengembangan konten interaktif mata pelajaran Simulasi dan Komunikasi Digital berstrategi blended learning di Kelas X SMK Negeri 3 Singaraja yaitu menggunakan model pengembangan ADDIE. [13] mengatakan model ADDIE merupakan salah satu model pengembangan yang dapat digunakan dalam penelitian pengembangan. Model ADDIE dapat memberi kesempatan untuk melakukan evaluasi terhadap aktivitas pengembangan pada setiap tahapan. Model ADDIE terdiri atas lima tahap yaitu: (1) Analisis (Analyze); (2) Perencanaan (Design); (3)Pengembangan (Development); (4) Implementasi (Implementation); dan (5) Evaluasi (Evaluation). Tahap analisis merupakan tahap dimana peneliti menganalisis perlunya pengembangan konten pembelajaran dan menganalisis kelayakan serta syarat-syarat pengembangan, Tahap desain merupakan tahap dalam memindahkan informasi yang telah diperoleh dari tahap analisis ke dalam bentuk desain yang akan menjadi tujuan dari pengembangan konten pembelajaran, Tahap pengembangan merupakan tahap penerjemahan desain ke dalam produk yang sesungguhnya, tahap Implementasi dilakukan untuk mengetahui kualitas pengembangan konten interaktif yang dilakukan dengan melakukan uji coba perorangan, uji coba kelompok kecil dan uji coba lapangan, lalu tahap evaluasi dilakukan berdasarkan setiap tahapan untuk mengevaluasi pengembangan konten pembelajaran interaktif.

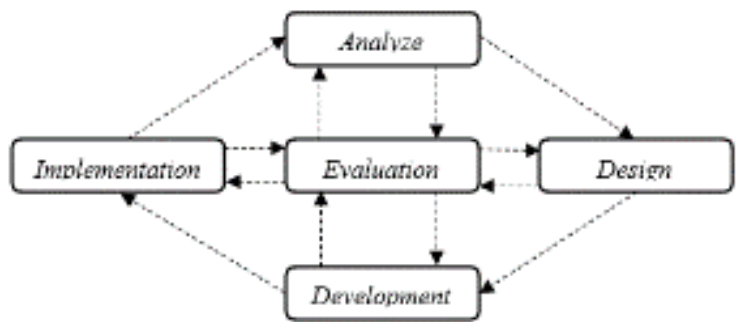

Gambar 1. Model Pengembangan ADDIE

C. Subjek Penelitian

Subjek pada penelitian ini adalah peserta didik kelas XI Multimedia di SMK Negeri 3 Singaraja mata pelajaran 


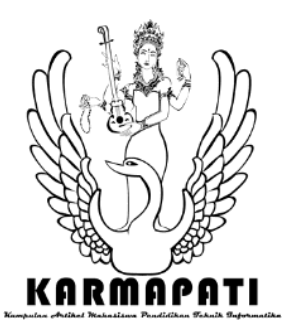

e-ISSN: 2685-7006 | p-ISSN: 2252-9063

Kumpulan Artikel Mahasiswa Pendidikan Teknik Informatika

(KARMAPATI)

Volume 10, Nomor 2, Tahun 2021

Simulasi dan Komunikasi Digital dengan jumlah peserta didik keseluruhan yaitu 31 orang.

D. Uji Coba Produk

1. Tahap Review Para Ahli

Review para ahli memiliki tujuan untuk mendapatkan pendapat ahli mengenai berbagai aspek terkait pengembangan konten pembelajaran interaktif. Adapun data yang diperlukan yaitu ketetapan isi oleh ahli isi dan desain fisik dari ahli media pembelajaran.

\section{Uji Coba Perorangan}

Tahap uji coba perorangan yaitu melibatkan subjek 3 orang siswa kelas XI Multimedia pada SMK Negeri 3 Singaraja. Dengan hasil belajar satu orang siswa dengan prestasi belajar Simulasi dan Komunikasi Digital tinggi, satu orang siswa prestasi belajar Simulasi dan Komunikasi Digital sedang, dan satu orang siswa prestasi belajar Simulasi dan Komunikasi Digital rendah.

\section{Uji Coba Kelompok Kecil}

Uji coba kelompok kecil dilakukan dengan melibatkan subjek yang terdiri dari 9 orang siswa. Subjek uji coba pada uji coba kelompok kecil ini berjumlah 9 orang siswa dari kelas XI Multimedia SMK Negeri 3 Singaraja. 9 orang siswa tersebut terdiri atas 3 orang siswa berprestasi belajar Simulasi dan Komunikasi Digital tinggi, 3 orang siswa berprestasi belajar Simulasi dan Komunikasi Digital sedang, dan 3 orang siswa berprestasi belajar Simulasi dan Komunikasi Digital rendah.

\section{Uji Lapangan}

Uji coba lapangan dilakukan dengan melibatkan subjek dari seluruh siswa kelas XI Multimedia SMK Negeri 3 Singaraja yang berjumlah 30 orang. Tujuan uji coba lapangan ini adalah untuk mendapatkan data yang akan digunakan untuk mengetahui kekurangan dan kelemahan produk yang dikembangkan sebagai dasar untuk melakukan revisi produk konten pembelajaran interaktif.

\section{E. Metode Pengumpulan Data}

Dalam pengumpulan data menggunakan tiga metode yaitu: wawancara, angket dan observasi. Data yang dikumpulkan pada penelitian ini mencakup data kualitatif dan kuantitatif yang meliputi informasi sumber belajar dan kegiatan pembelajaran, karakteristik peserta didik, kevalidan konten pembelajaran melalui validasi serta respons peserta didik dan guru terhadap media pembelajaran yang dikembangkan. Metode wawancara digunakan untuk mencari informasi tentang sumber belajar yang digunakan dalam proses pembelajaran serta untuk mengetahui bagaimana karakteristik dari peserta didik berdasarkan pertanyaan dalam pedoman wawancara yang sudah dipersiapkan. Angket digunakan untuk mengetahui respon guru dan peserta didik terhadap produk konten pembelajaran interaktif yang dikembangkan, validasi yang dilakukan ahli isi dan ahli media serta uji coba perorangan, uji coba kelompok kecil dan uji lapangan dilakukan pengumpulan data dengan menggunakan angket. Untuk uji ahli terdiri dari dua pilihan jawaban pada angket yaitu sesuai dan tidak sesuai, sedangkan uji perorangan, uji kelompok kecil, uji lapangan yang dilakukan kepada siswa pada tahapan implementasi dan repon guru serta respon peserta didik menggunakan angket skala likert

Tabel 1. Metode Pengumpulan Data

\begin{tabular}{|l|c|c|l|}
\hline \multicolumn{1}{|c|}{ Jenis Data } & Metode & $\begin{array}{c}\text { Alat } \\
\text { Pengumpulan } \\
\text { Data }\end{array}$ & \multicolumn{1}{|c|}{ Sumber Data } \\
\hline $\begin{array}{l}\text { Informasi } \\
\text { sumber } \\
\text { belajar dan } \\
\text { kegiatan } \\
\text { pembelajaran }\end{array}$ & Wawancara & $\begin{array}{c}\text { Pedoman } \\
\text { Wawancara }\end{array}$ & $\begin{array}{l}\text { Guru mata pelajaran } \\
\text { Simulasi dan } \\
\text { Komunikasi Digital } \\
\text { kelas X di SMK } \\
\text { Negeri 3 Singaraja, }\end{array}$ \\
\hline $\begin{array}{l}\text { Karakteristik } \\
\text { peserta didik }\end{array}$ & Wawancara & Pedoman & $\begin{array}{l}\text { Peserta didik kelas } \\
\text { XI Multimedia di } \\
\text { SMK Negeri 3 }\end{array}$ \\
\hline $\begin{array}{l}\text { Kevalidan } \\
\text { konten } \\
\text { pembelajaran }\end{array}$ & $\begin{array}{c}\text { Penyembarana } \\
\text { Instrumen }\end{array}$ & Angket & $\begin{array}{l}\text { Ahli isi } \\
\text { pembelajaran dan } \\
\text { Ahli media } \\
\text { pembelajaran }\end{array}$ \\
\hline $\begin{array}{l}\text { Respon guru } \\
\text { dan peserta } \\
\text { didik }\end{array}$ & $\begin{array}{c}\text { Penyebaran } \\
\text { Instrumen }\end{array}$ & Angket & $\begin{array}{l}\text { Guru mata pelajaran } \\
\text { Simulasi dan } \\
\text { Komunikasi Digital } \\
\text { kelas X dan Peserta } \\
\text { didik kelas XI } \\
\text { Multimedia di SMK } \\
\text { Negeri 3 Singaraja, }\end{array}$ \\
& & & \\
\hline
\end{tabular}

F. Instrumen Pengumpulan Data

Instrumen pengumpulan data merupakan instrumen yang digunakan untuk mendapatkan data dan informasi yang dibutuhkan berdasarkan metode pengumpulan data yang digunakan, seperti pedoman wawancara dan daftar pertanyaan pada angket. Pedoman wawancara digunakan untuk mengumpulkan data dan informasi sumber belajar, kegiatan pembelajaran dan karakteristik peserta didik. Lalu instrument angket digunakan untuk pengumpulan data uji ahli isi, uji ahli media, uji perorangan, uji kelompok kecil, uji lapangan, uji respon peserta didik dan uji respon guru mata pelajaran.

G. Analisis Data Kevalidan Konten Pembelajaran 


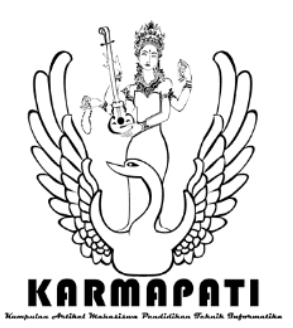

e-ISSN: 2685-7006 | p-ISSN: 2252-9063

Kumpulan Artikel Mahasiswa Pendidikan Teknik Informatika

(KARMAPATI)

Volume 10, Nomor 2, Tahun 2021

Analisis data kevalidan konten pembelajaran dimaksud untuk mengetahui sejauh mana konten pembelajaran yang dibuat dapat memenuhi kriteria berdasarkan penilaian validator yang ditunjuk dengan menggunakan lembar uji validasi ahli Gregory [14] mengembangkan teknik dalam pengujian validitas isi adalah sebagai berikut:

a. Para pakar yang dipercaya menilai instrumen dan melakukan penilaian instrumen per butir,

b. Pengelompokan skala dikelompokkan menjadi kurang relevan dan sangat relevan,

c. Hasil penilaian para pakar di tabulasi silang, misalnya untuk dua penilai seperti Tabel 2 berikut.

Tabel 1. Metode Pengumpulan Data

\begin{tabular}{|c|c|c|c|}
\cline { 3 - 4 } \multicolumn{2}{c|}{} & \multicolumn{2}{c|}{ PENILAI 1 } \\
\cline { 3 - 4 } \multicolumn{2}{c|}{} & $\begin{array}{c}\text { TIDAK } \\
\text { SESUAI }\end{array}$ & SESUAI \\
\hline \multirow{3}{*}{ PENILAI 2} & TIDAK & (A) & (B) \\
& SESUAI & (C) & (D) \\
\cline { 2 - 4 } & SESUAI & S)
\end{tabular}

Berikut perhitungan validitas konten pembelajaran dengan

rumus: Validasi $=\frac{D}{A+B+C+D}=$

Keterangan:

A

Sel yang menunjukkan ketidaksetujuan antara kedua penilai

$\mathrm{B}$ dan $\mathrm{C} \quad$ : Sel yang menunjukkan perbedaan pandangan antara penilai

D : Sel yang menunjukkan persetujuan valid antara kedua penilai

Untuk dapat melihat tingkat pencapian dari penilaian yang diberikan dari setiap uji ahli isi dan uji ahli media yang dilakukan dapat dilihat pada Tabel 3 berikut.

Tabel 3. Kriteria Tingkat Validasi Uji Ahli

\begin{tabular}{|l|l|l|}
\hline $\begin{array}{c}\text { Koefesien } \\
\text { Validitas }\end{array}$ & Tingkat Validitas & \multicolumn{1}{|c|}{ Kriteria } \\
\hline $0,91-1,00$ & Sangat Tinggi & Sangat Valid \\
\hline $0,71-0,90$ & Tinggi & Valid \\
\hline $0,41-0,70$ & Cukup & Cukup Valid \\
\hline $0,21-0,40$ & Rendah & Kurang Valid \\
\hline $0,01-0,20$ & Sangat Rendah & $\begin{array}{l}\text { Sangat Kurang } \\
\text { Valid }\end{array}$ \\
\hline
\end{tabular}

\section{HASIL DAN PEMBAHASAN}

A. Hasil

Hasil yang didapatkan dari penelitian ini adalah sebuah produk konten pembelajaran interaktif yang digunakan pada mata pelajaran Simulasi dan Komunikasi Digital kelas X di SMK Negeri 3 Singaraja dengan menggunakan model pengembangan ADDIE. Dalam sebuah pengembangan konten pembelajaran interaktif dapat dikatakan valid apabila dapat digunakan sebagai sumber belajar oleh peserta didik. Oleh karena itu, perlu dilakukan pengujian oleh beberapa pakar dan juga oleh peserta didik yang akan menggunakan produk ini dalam pembelajaran. Pengujian konten interaktif ini dilakukan oleh para pakar diantaranya, ahli isi dan ahli media. Sedangkan dalam pengujiannya ke peserta didik dilakukan melalui uji coba perorangan, uji coba kelompok kecil dan uji coba lapangan serta dilengkapi dengan uji efektivitas dan uji respon peserta didik dan uji respon guru Mengenai pemaparan hasil penelitian dan pengujian akan dijelaskan sebagai berikut.

1) Hasil Tahap Analisis (Analyze)

Hasil analisis tempat penelitian berdasarkan observasi yang telah dilakukan di SMK Negeri 3 Singaraja memperoleh hasil yaitu ruang belajar dan kelengkapan ruang belajar peserta didik sudah dapat mendukung kenyamanan peserta didik dalam mengikuti kegiatan pembelajaran. Selain itu untuk kebutuhan pembelajaran yang membutuhkan fasilitas komputer yang memadai juga sudah disediakan dengan baik oleh sekolah di ruang laboratorium/bengkel. Fasilitas-fasiitas penunjang kegiatan pembelajaran lainnya juga sudah tersedia seperti alat praktikum, LCD, proyektor serta akses internet.

Hasil analisis sumber belajar pada mata pelajaran Simulasi dan Komunikasi Digital memperoleh hasil yaitu, sumber belajar yang digunakan dalam kegiatan pembelajaran di SMK Negeri 3 Singaraja berupa buku paket dan juga dilengkapi dengan sumber belajar dari internet yang dikemas dalam bentuk modul pembelajaran yang dibuat langsung oleh guru mata pelajaran Simulasi dan Komunikasi Digital. Selain dalam bentuk modul ajar, guru juga menggunakan sumber belajar berupa video pembelajaran sesuai dengan materi yang sedang dibahas pada proses pembelajaran. Video tersebut juga merupakan sebuah sumber belajar yang didapatkan dari internet sebagai rujukan untuk pembelajaran peserta didik.

Hasil dari analisis mata pelajaran Simulasi dan Komunikasi Digital yaitu memperoleh informasi mengenai kompetensi Inti (KI), Kompetensi dasar (KD), Indikator Zencapaian Kompetensi (IPK) serta materi pembelajaran pada semester genap yang dikembangkan dalam bentuk konten interaktif yang akan didistribusikan melalui LMS yang digunakan oleh sekolah. Terdapat dua kompetensi dasar yang 


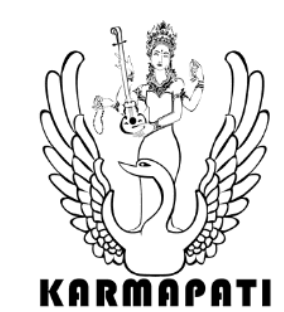

harus dikuasai oleh peserta didik yaitu dokumen praproduksi video dan juga proses produksi video.

Hasil dari analisis karakteristik peserta didik berdasarkan wawancara yang telah dilakukan kepada peserta didik, dapat diperoleh hasil bahwa peserta didik senang dalam mengikuti kegiatan pembelajaran Simulasi da Komunikasi Digital karena menurut mereka materi yang diberikan menarik untuk di pelajari. Walaupun menarik, ada beberapa materi yang masih membuat siswa kesulitan untuk memahami penjelasanpenjelasan di dalamnya karena mengandung istilah-istilah yang mungkin baru mereka temui. Selain itu siswa akan lebih senang dan termotivasi jika konten pembelajaran yang diberikan merupakan kombinasi dari teks, gambar, suara, video dan juga animasi dan dapat langsung berinteraksi dengan mereka.

2) Hasil Tahap Desain (Design)

Hasil perancangan tahap desain pengembangan konten dan materi pembelajaran yaitu berupa penetapan kompetensi inti dan kompetensi dasar dalam bentuk tujuan pembelajaran sesuai dengan silabus mata pelajaran Simulasi dan Komunikasi Digital, penetapan materi pembelajaran Simulasi dan Komunikasi Digital yang pada penelitian ini mengambil materi (1) Konsep pembuatan video, (2) Sinopsis, (3) Naskah, (4) Storyboard, (5) Sinematografi, (6) Pengoperasian kamera, (7) Pencahayaan. Keseluruhan materi tersebut akan dikemas ke dalam sebuah konten interaktif dengan desain sebagai berikut.

Tahapan desain penyusunan rencana pelaksanaan pembelajaran (RPP) dilakukan dengan menyesuaikan format RPP yang digunakan di SMK Negeri 3 Singaraja sebagai pedoman dalam proses penyusunan RPP dan disesuaikan dengan tahapan strategi pembelajaran blended learning pada kegiatan inti pembelajaran.

Tahapan desain pengembangan konten pembelajaran interaktif dilakukan dengan merancang tampilan antarmuka dalam bentuk mockup dari konten pembelajaran interaktif yang akan dikembangkan disesuaikan dengan menu-menu yang akan ada berdampingan dengan konten interaktif. Menu yang akan disediakan dalam pengembangannya yaitu (1) Tujuan pembelajaran, (2) Materi pembelajaran, (3) Video pembelajaran, (4) Latihan soal, (5) Evaluasi pembelajaran, (6) Referensi dan atribusi, (7) bantuan, (8), Profil pengembang. Kegiatan perancangan yang dilakukan pada tahap ini yaitu difokuskan pada pengembangan konten interaktif dalam mengemas materi pembelajaran, dan fungsi-fungsi dari setiap menu yang dirancang. Sedangkan Lembar Kerja Peserta Didik
e-ISSN: 2685-7006 | p-ISSN: 2252-9063

(KARMAPATI)

Volume 10, Nomor 2, Tahun 2021
(LKPD) dan soal evaluasi terletak diluar konten pembelajaran interaktif. Selain itu, pada tahap ini juga dirancang pemetaan berupa struktur dari konten interaktif yang dikembangkan seperti Gambar 1 berikut.

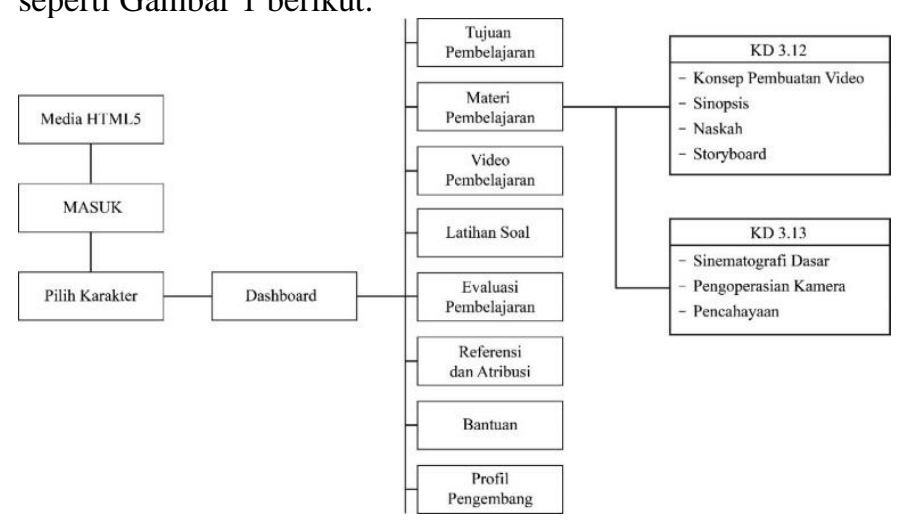

Gambar 1. Perancangan Struktur Konten Interaktif

3) Hasil tahap Pengembangan (Development)

Hasil dari pengembangan konten pembelajaran interaktif pada mata pelajaran Simulasi dan Komunikasi Digital menggunakan teknologi Articulate Storyline 3 yang memungkinkan pengaksesan konten interaktif melalui Html 5 yang didistribusikan melalui LMS Google Classroom yang digunakan di SMK Negeri 3 Singaraja. Pengaksesan fitur-fitur pada konten pembelajaran interaktif tentunya akan bisa dilakukan oleh peserta didik yang telah login terlebih dahulu di LMS yang digunakan oleh Sekolah. Penggunaan konten interaktif ini didasarkan pada manfaat pengguna, dimana pengguna dalam hal ini adalah guru sebagai tenaga pendidik dan siswa sebagai peserta didik. Hasil dari pengembangan konten pembelajaran interaktif berdasarkan rancangan yang telah dibuat pada tahap desain dapat dilihat sebagai berikut.

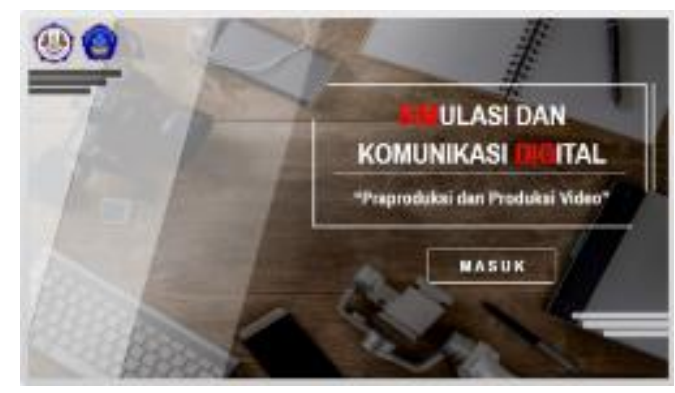

Gambar 2. Halaman Awal 


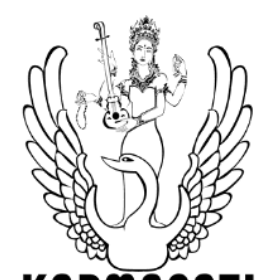

KคRmAPดTI

e-ISSN: 2685-7006 | p-ISSN: 2252-9063

Kumpulan Artikel Mahasiswa Pendidikan Teknik Informatika

(KARMAPATI)

Volume 10, Nomor 2, Tahun 2021

Berisikan nama mata pelajaran, materi pembelajaran, logo sekolah, logo universitas dan tombol masuk

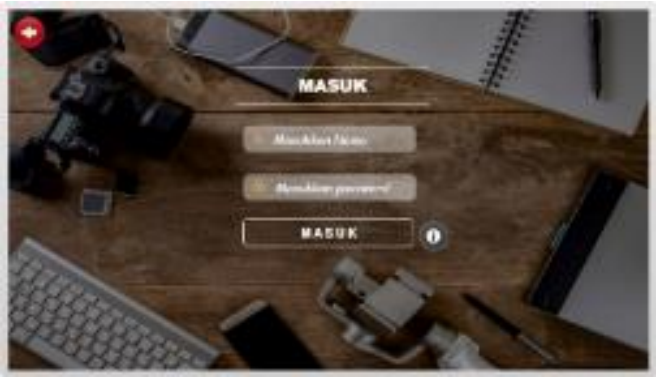

Gambar 3. Login

Memuat tombol kembali dan form login yang terdiri dari nama lengkap dan password lalu tombol masuk

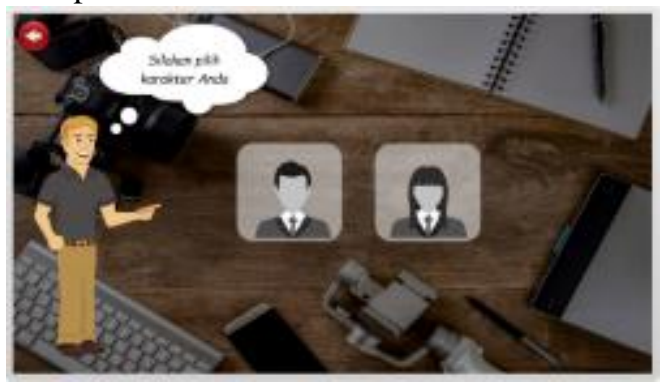

Gambar 4. Pilih Karakter

Peserta didik dapat memilih karakter atau jenis gender antara perempuan dan juga lai-laki yang akan ditampilkan pada dashboard.

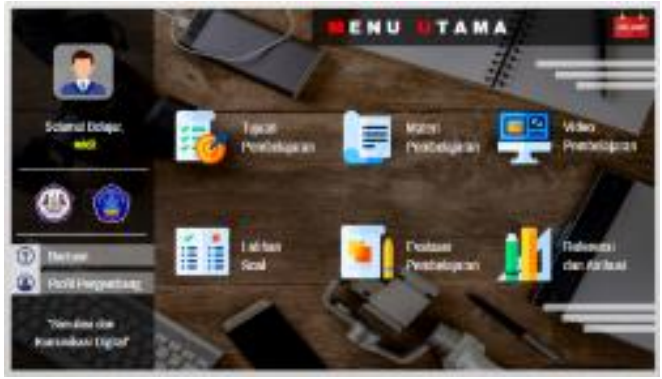

Gambar 5. Dahboard

Memuat menu-menu berkaitan dengan konten pembelajaran interaktif. Selain itu juga terdapat tombol keluar dari dashboard.

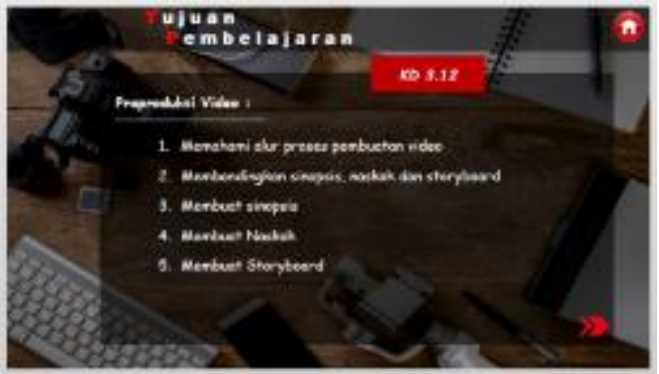

Gambar 6. Tujuan Pembelajaran

Berisikan pemaparan tujuan pembelajaran dari KD 3.12 dan KD 3.13.

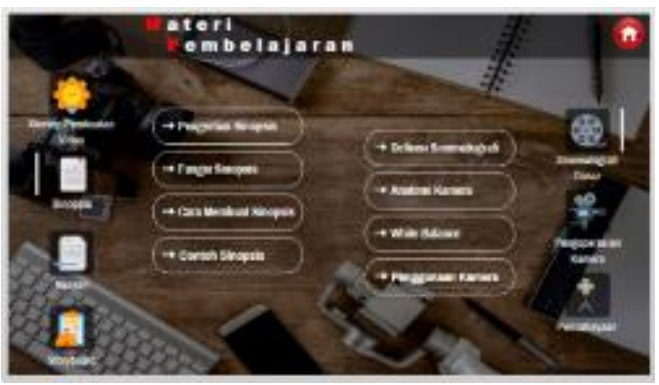

Gambar 7. Materi Pembelajaran

Memuat seluruh materi pembelajaran yang dikemas menjadi konten interaktif.

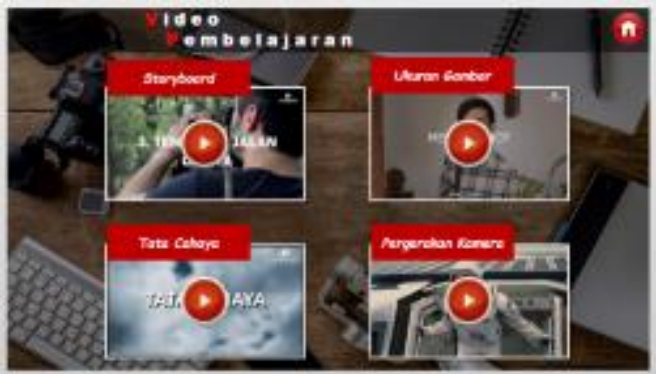

Gambar 8. Video Pembelajaran

Memuat sejumlah video pembelajaran berdasarkan dengan materi pembelajaran yang diberikan 

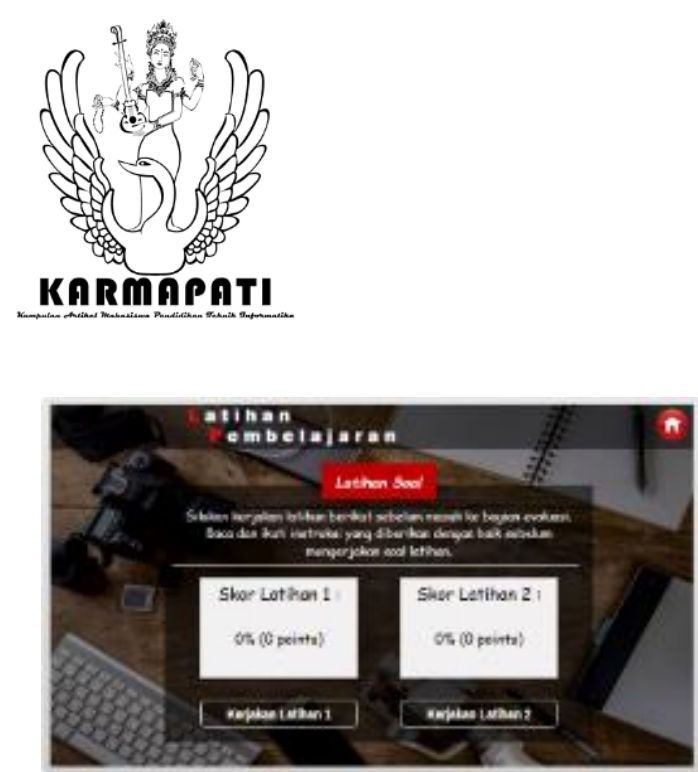

Gambar 9. Latihan Soal

Menampilkan instruksi awal pengerjaan latihan soal, skor dan tombol untuk menuju pengerjaan soal

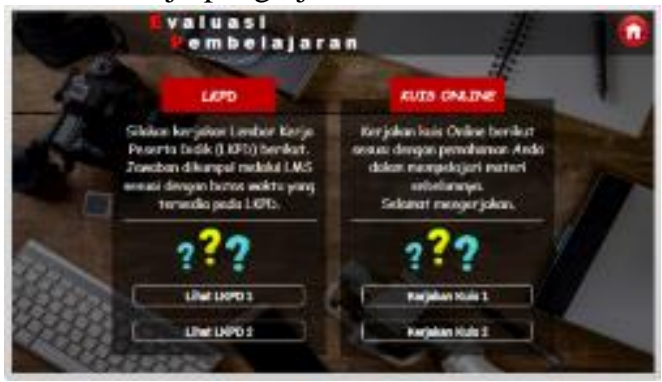

Gambar 10. Evaluasi Pembelajaran

Berisikan instruksi pengerjaan LKPD dan kuis online serta tombol untuk mengakses LKPD dan kuis online.

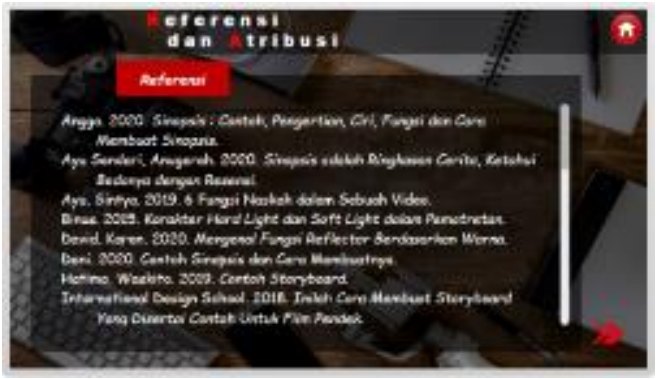

Gambar 11. Referensi dan Atribusi

Memuat seluruh referensi dari materi pembelajaran dan atribusi asset-asset dan video yang digunakan
e-ISSN: 2685-7006 | p-ISSN: 2252-9063

Kumpulan Artikel Mahasiswa Pendidikan Teknik Informatika

(KARMAPATI)

Volume 10, Nomor 2, Tahun 2021

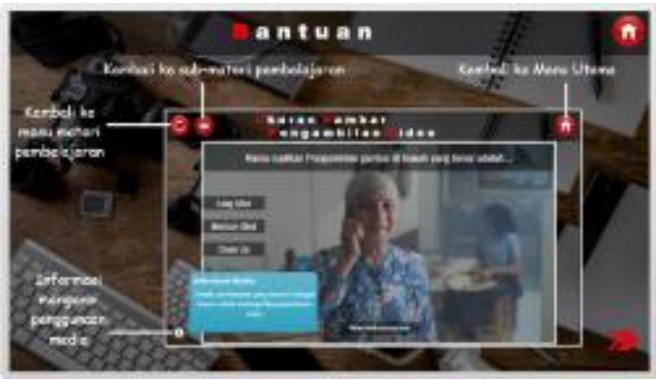

Gambar 12. Bantuan

Berisikan penjelasan mengenai fungsi-fungsi tombol pada konten interaktif dan media

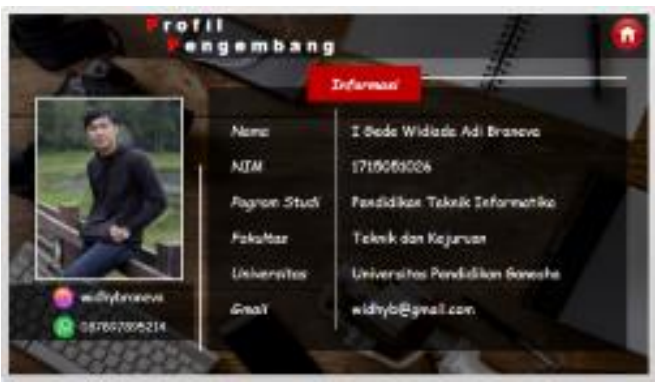

Gambar 13. Profil Pengembang

Berisikan informasi mengenai profil pengembang media dan konten interaktif

Validitas konten interaktif mata pelajaran Simulasi dan Komunikasi Digital diperoleh dari hasil penilaian dan juga revisi dari para ahli/pakar yeng meliputi ahli isi dan ahli media pembelajaran. Dari hasil pengujian validitas ahli isi berdasarkan penilaian yang diberikan melalui angket ahli isi didapatkan hasil perhitungan 1,00 yang menunjukan bahwa isi dari produk yang dikembangkan berada pada kriteria "Sangat Valid". Selanjutnya untuk validitas ahli media melalui penilaian instrument angket ahli media diperoleh hasil perhitungan yaitu 1,00 yang menunjukkan bahwa produk konten interaktif ini berada pada kriteria "Sangat Valid". Oleh karena itu didapatkan perhitungan rata-rata dari pengujian validitas ahli dapat dilihat pada Tabel 4 berikut.

Tabel 4. Rata-Rata Hasil Pengujian Validitas Ahli

\begin{tabular}{|c|c|}
\hline Pengujian Ahli & Hasil Perhitungan \\
\hline Ahli Isi & 1,00 \\
\hline
\end{tabular}


e-ISSN: 2685-7006 | p-ISSN: 2252-9063

Kumpulan Artikel Mahasiswa Pendidikan Teknik Informatika

(KARMAPATI)

Volume 10, Nomor 2, Tahun 2021

KaRmapaTI

\begin{tabular}{|l|c|}
\hline Ahli Media & 1,00 \\
\hline Rata-rata & 1,00 \\
\hline
\end{tabular}

3) Hasil Tahap Implementasi (Implementation)

a. Uji Coba Perorangan

Hasil persentase yang didapatkan dan dikonversikan maka berdasarkan tingkat persentase pencapaian sebesar $95 \%$ berada pada kualifikasi "Sangat Baik" dengan kriteria yang didapatkan yaitu "Sangat Valid" dan persenase pada tingkat pencapaian per kategori diperoleh hasil yaitu sangat baik $100 \%$, baik $0 \%$, cukup $0 \%$, kurang $0 \%$, dan sangat kurang sebesar $0 \%$.

Tabel 5. Rekapitulasi Penilaian Uji Coba Perorangan

\begin{tabular}{|l|c|c|}
\hline $\begin{array}{c}\text { Konversi } \\
\text { Tingkat } \\
\text { Pencapaian }\end{array}$ & Persentase (\%) & $\begin{array}{c}\text { Jumlah } \\
\text { Responden } \\
\text { (Orang) }\end{array}$ \\
\hline Sangat Baik & 100 & 3 \\
\hline Baik & 0 & 0 \\
\hline Cukup & 0 & 0 \\
\hline Kurang & 0 & 0 \\
\hline Sangat Kurang & 0 & 0 \\
\hline
\end{tabular}

\section{Uji Coba Perorangan}

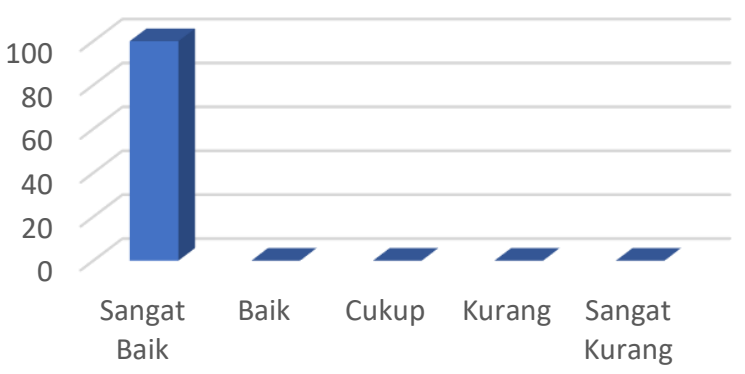

Gambar 14. Grafik Hasil Uji Coba Perorangan

b. Uji Coba Kelompok Kecil

Hasil persentase yang didapatkan dan dikonversikan maka berdasarkan tingkat persentase pencapaian sebesar 89,5\% berada pada kualifikasi "Baik Baik" dengan kriteria yang didapatkan yaitu "Valid" dan persenase pada tingkat pencapaian per kategori diperoleh hasil yaitu sangat baik 50\%, baik $50 \%$, cukup $0 \%$, kurang $0 \%$, dan sangat kurang sebesar $0 \%$.

Tabel 6. Rekapitulasi Penilaian Uji Coba Kelompok Kecil

\begin{tabular}{|l|c|c|}
\hline $\begin{array}{c}\text { Konversi } \\
\text { Tingkat } \\
\text { Pencapaian }\end{array}$ & Persentase (\%) & $\begin{array}{c}\text { Jumlah } \\
\text { Responden } \\
\text { (Orang) }\end{array}$ \\
\hline Sangat Baik & 50 & 5 \\
\hline Baik & 50 & 5 \\
\hline Cukup & 0 & 0 \\
\hline Kurang & 0 & 0 \\
\hline Sangat Kurang & 0 & 0 \\
\hline
\end{tabular}

\section{Uji Coba Kelompok Kecil}

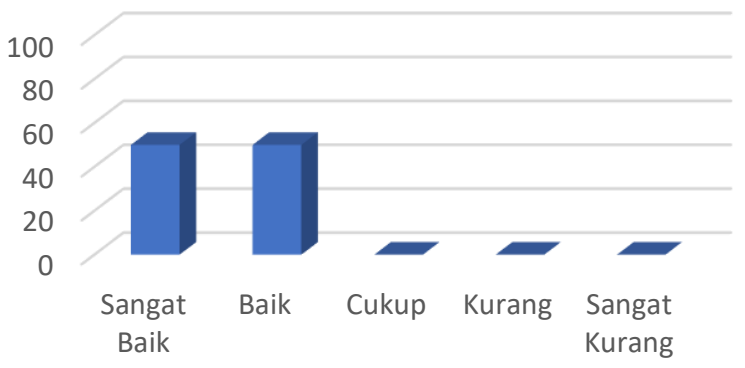

Gambar 15. Grafik Hasil Uji Coba Kelompok Kecil

c. Uji Coba Lapangan

hasil persentase yang didapat dikonversikan maka berdasarkan tingkat persentase pencapaian sebesar $92,64 \%$ berada pada kualifikasi "Sangat Baik" dengan kriteria yang didapatkan yaitu "Sangat Valid" dan persenase pada tingkat pencapaian per kategori diperoleh hasil yaitu sangat baik $74,20 \%$, baik $25,80 \%$, cukup $0 \%$, kurang $0 \%$, dan sangat kurang sebesar $0 \%$.

Tabel 7. Rekapitulasi Penilaian Uji Coba Lapangan

\begin{tabular}{|l|c|c|}
\hline $\begin{array}{c}\text { Konversi } \\
\text { Tingkat } \\
\text { Pencapaian }\end{array}$ & Persentase (\%) & $\begin{array}{c}\text { Jumlah } \\
\text { Responden } \\
\text { (Orang) }\end{array}$ \\
\hline Sangat Baik & 74,20 & 23 \\
\hline Baik & 25,80 & 8 \\
\hline Cukup & 0 & 0 \\
\hline Kurang & 0 & 0 \\
\hline Sangat Kurang & 0 & 0 \\
\hline
\end{tabular}




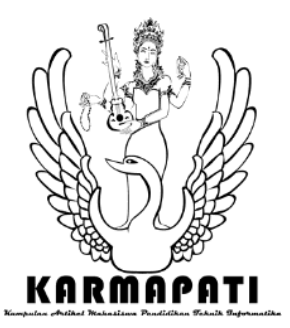

e-ISSN: 2685-7006 | p-ISSN: 2252-9063

Kumpulan Artikel Mahasiswa Pendidikan Teknik Informatika

(KARMAPATI)

Volume 10, Nomor 2, Tahun 2021

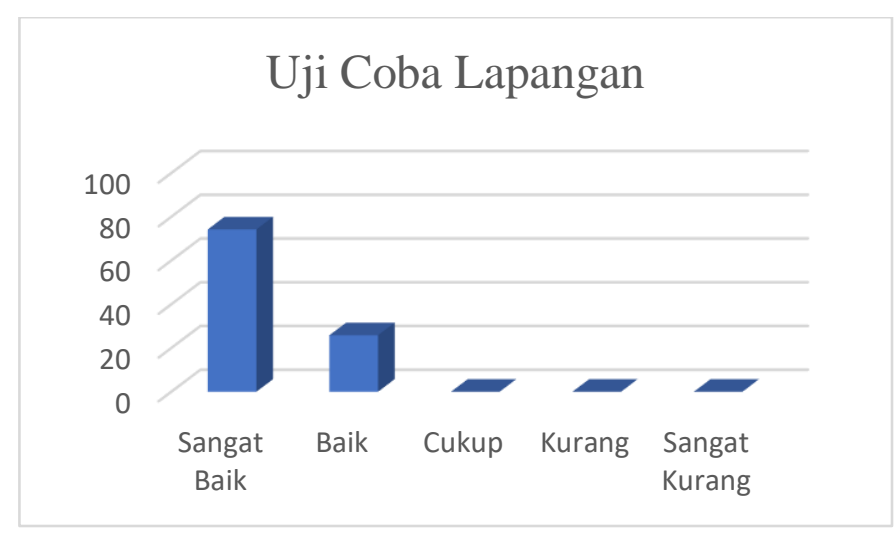

Gambar 16. Grafik Hasil Uji Coba Lapangan

d. Uji Respon Pesesrta Didik

Dari hasil penilaian yang diberikan oleh 31 peserta didik dengan jumlah skor sebanyak 2136. Setelah dilakukan konversi ke dalam tabel kriteria penggolongan respon peserta didik, hasil dari rata-rata $(\bar{x})$ respon peserta didik menunjukkan nilai 68,9 yang termasuk ke dalam kategori "Sangat Positif" dengan kriteria "Sangat Praktis". Hal tersebut menunjukkan bahwa pengembangan konten interaktif mata pelajaran Simulasi dan Komunikasi Digital sudah berada pada kriteria "Sangat Praktis" dan dibuktikan juga dengan komentar yang diperoleh pada angket respon yang sebelumnya telah disebar ke peserta didik mendapatkan respon yang positif terhadap pengembangan konten interaktif mata pelajaran Simulasi dan Komunikasi Digital.

\section{e. Uji Respon Guru}

Dari hasil penilaian yang diberikan oleh guru dengan jumlah skor 47. Hasil yang diperoleh dari respon guru dengan rata-rata $(\bar{x}) 47$ termasuk ke dalam kategori "Sangat Positif" dengan kriteria "Sangat Praktis". Hal tersebut menunjukkan bahwa pengembangan konten interaktif mata pelajaran Simulasi dan Komunikasi Digital sudah berada pada kriteria "Sangat Praktis" yang dibuktikan juga dengan tidak adanya saran ataupun masukkan yang perlu untuk dilakukan perbaikan terhadap konten pembelajaran interaktif mata pelajaran Simulasi dan Komunikasi Digital.

4) Hasil tahap Evaluasi (Evaluation)

Dari keseluruhan aspek terkait pelaksanaan evaluasi pada setiap tahapan model pengembangan ADDIE sudah dilaksankan sesuai dengan instrument dan indikator yang telah ditentukan. Validitas konten interaktif mata pelajaran Simulasi dan Komunikasi Digital diperoleh dari hasil penilaian dan juga revisi dari para ahli/pakar yeng meliputi ahli isi dan ahli media pembelajaran. Dari hasil pengujian validitas ahli isi berdasarkan penilaian yang diberikan melalui angket ahli isi didapatkan hasil perhitungan 1,00 yang menunjukan bahwa isi dari produk yang dikembangkan berada pada kriteria "Sangat Valid". Selanjutnya untuk validitas ahli media melalui penilaian instrumen angket ahli media diperoleh hasil perhitungan yaitu 1,00 yang menunjukkan bahwa produk konten interaktif ini berada pada kriteria "Sangat Valid". Selain itu, uji efektivitas dari konten pembelajaran interaktif mata pelajaran Simulasi dan Komunikasi Digital dilakukan dengan memberikan soal berupa soal pre-test dan soal post-test untuk mengetahui perbandingan nilai yang diperoleh oleh peserta didik sebelum dan sesudah diimplementasikannya penggunaan konten interaktif mata pelajaran Simulasi dan Komunikasi Digital Gain sebesar 0,91 sehingga uji efetivitas yang dilakukan berada pada kriteria "Efektif" merujuk pada tabel kategori skor Gain menurut [15].

B. Pembahasan

Konten pembelajaran interaktif mata pelajaran Simulasi dan Komunikasi Digital ini memiliki peran sebagai bahan ajar dan konten pembelajaran yang tentunya dapat membantu guru untuk mempermudah penyampaian materi pembelajaran. Peran guru dalam konten interaktif ini adalah sebagai fasilitator yang dapat memfasilitasi peserta didik dalam seluruh proses pembelajaran yang dilakukan pada konten interaktif ini. Pengimplementasian konten interaktif ini disesuaikan dengan strategi pembelajaran blended learning. Strategi atau model pembelajaran blended learning merupakan sebuah model pembelajaran yang menggabungkan pembelajaran tatap muka dengan pembelajaran daring. Penggunaan strategi atau model pembelajaran ini merujuk pada penjelasan [16] dikarenakan dapat menyesuaikan dengan kondisi pembelajaran dari rumah seperti saat ini dengan memanfaatkan pembelajaran tatap muka atau live event yang mendukung pembelajaran dilakukan secara langsung pada waktu yang sama tetapi pada tempat yang berbeda atau dapat disebut dengan virtual classroom dan juga mendukung pembelajaran mandiri atau self-paced learning yang memungkinkan peserta didik dapat belajar kapan saja dan dimana saja secara online dengan menggunakan konten interaktif yang dikembangkan. [17] mengemukakan pengembangan sebuah konten yang digunakan dalam kegiatan pembelajaran dapat menambah semangat dan motivasi belajar yang dimiliki oleh peserta didik dalam kegiatan pembelajaran. 


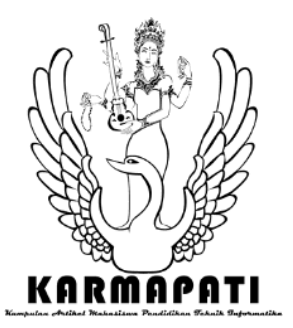

e-ISSN: 2685-7006 | p-ISSN: 2252-9063

Kumpulan Artikel Mahasiswa Pendidikan Teknik Informatika

(KARMAPATI)

Volume 10, Nomor 2, Tahun 2021

Dalam dukungan pengimplementasian konten interaktif ini kepada peserta didik, maka dimanfaatkan sebuah media berupa learning management system google classroom untuk mendistribusikan dan melakukan kegiatan pembelajaran secara online agar kemudahan dan kenyamanan dalam belajar pada tempat yang berbeda dapat dirasakan oleh peserta didik. Selain itu inovasi dan variasi dari konten interaktif yang menghadirkan stimulus dan respon dari peserta didik dan konten dapat diterapkan dengan strategi pembelajaran blended learning dimana akan menghadirkan proses pembelajaran yang bervariasi dimana pembelajaran mandiri secara daring tidak menggantikan pembelajaran live event atau virtual classroom tetapi kedua sistem pembelajaran tersebut dapat saling melengkapi. Dalam penerapannya, blended learning memiliki 3 fase pembelajaran yaitu diantaranya adalah (1) fase seeking of information yang dilakukan dalam bentuk pencarian informasi pembelajaran melalui materi yang terdapat dalam konten interaktif dan video pembelajaran, (2) fase acquisition of information yang diterapkan dalam bentuk menginstruksikan peserta didik untuk mengerjakan tugas yang diberikan guru berupa LKPD dan memberikan kesempatan peserta didik untuk melakukan diskusi, (3) fase synthesizing of knowledge yaitu dengan menyimpulkan pembelajaran dan melakukan pengumpulan tugas yang diberikan sesuai dengan instruksi atau arahan dari guru.

Uji respon konten interaktif mata pelajaran Simulasi dan Komunikasi Digital didapatkan melalui hasil pengujian respon peserta didik dan uji respon guru mata pengampu mata pelajaran terhadap konten interaktif mata pelajaran Simulasi dan Komunikasi Digital. Hasil perolehan nilai rata-rata dari uji respon peserta didik berada pada kriteria "Sangat Praktis". Sedangkan perolehan rata-rata hasil respon guru pengampu mata pelajaran Simulasi dan Komunikasi Digital berada pada kriteria "Sangat Praktis". Berdasarkan hasil yang diperoleh dari uji kepraktisan yang dilakukan dengan uji respon peserta didik dan uji respon guru, maka dapat dikatakan bahwa kepraktisan konten interaktif mata pelajaran Simulasi dan Komunikasi Digital berada pada kriteria "Sangat Praktis".

Konten interaktif ini dikembangkan berdasarkan 3 teori belajar, diantaranya adalah teori belajar behavioristik, konstruktivisme dan kognitivisme. Teori belajar behavioristik memiliki pandangan bahwa belajar merupakan perubahan dalam bentuk tingkah laku akibat dari adanya interaksi antara stimulus dan respon. Teori belajar selanjutnya yang bekaitan dengan konten interaktif ini adalah teori belajar konstruktivisme. Teori belajar ini menyatakan bahwa belajar adalah suatu proses dalam membangun pengetahuan berdasarkan pengalaman langsung dari peserta didik. Teori belajar yang terakhir yaitu teori belajar kognitivisme, dimana pada teori belajar ini memiliki perspektif bahwa peserta didik memproses informasi materi pembelajaran melalui mengorganisir dan menemukan hubungan dari pengetahuan baru yang telah mereka dapatkan dengan pengetahuan yang sebelumnya telah mereka peroleh.

Konten interaktif mata pelajaran Simulasi dan Komunikasi Digital yang digunakan pada kelas XI SMK Negeri 3 Singaraja memiliki beberapa kelebihan dan kendala yang ditemukan selama pelaksanaan pembelajaran secara daring. Adapun kelebihan dari konten interaktif mata pelajaran Simulasi dan Komunikasi Digital dengan media distribusi berupa LMS Google Classroom antara lain: (1) Konten interaktif mata pelajaran Simulasi dan Komunikasi Digital dapat memudahkan peserta didik dalam belajar secara mandiri sesuai dengan kurikulum yang berlaku. (2) Konten interaktif mata pelajaran Simulasi dan Komunikasi Digital dapat membantu mengarahkan peserta didik untuk memahami materi pembelajaran yang diberikan melalui illustrasi-illustrasi dan juga simulasi yang disediakan dalam konten interaktif. (3) Konten interaktif mata pelajaran Simulasi dan Komunikasi Digital dapat mudah di akses kapan saja dan dimana saja dengan memanfaatkan laptop/komputer ataupun dengan menggunakan smartphone. (4) Dengan adanya konten interaktif mata pelajaran Simulasi dan Komunikasi Digital, peserta didik secara mandiri dapat memanfaatkan fitur lainnya di dalam media yang sama berupa latihan soal untuk mempersiapkan diri mengikuti evaluasi pembelajaran. (5) Dengan adanya konten interaktif mata pelajaran Simulasi dan Komunikasi Digital ini peserta didik dapat mengukur tingkat kemampuan melalui kuis yang tersedia didalamnya dan guru dapat mengetahui hasil nilai yang diperoleh peserta didik secara langsung.

\section{SIMPULAN DAN SARAN}

Berdasarkan hasil penelitian dan pembahasan pada penelitian pengembangan konten interaktif mata pelajaran Simulasi dan Komunikasi Digital berstrategi blended learning di kelas X SMK negeri 3 Singaraja, maka dapat ditarik kesimpulan yaitu hasil pengembangan dari konten interaktif mata pelajaran Simulasi dan Komunikasi Digital berstrategi blended learning di kelas X SMK negeri 3 Singaraja. berdasarkan hasil yang didapatkan dari pengujian ahli isi 


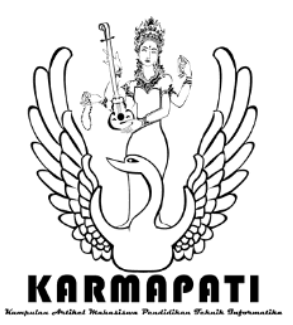

e-ISSN: 2685-7006 | p-ISSN: 2252-9063

Kumpulan Artikel Mahasiswa Pendidikan Teknik Informatika

(KARMAPATI)

Volume 10, Nomor 2, Tahun 2021

memperoleh skor 1,00 yang berada pada kriteria "Sangat Valid" dan hasil pengujian dari ahli media dengan perolehan skor 1,00 yang berada pada kriteria "Sangat valid". Selanjutnya untuk pengujian efektivitas konten interaktif mata pelajaran Simulasi dan Komunikasi Digital dengan perolehan nilai NGain sebesar 0,91 yang termasuk ke dalam kriteria "Efektif" dan 2. Hasil yang diperoleh dari uji respon peserta didik dan juga uji respon guru yang dilakukan setelah implementasi konten interaktif mata pelajaran Simulasi dan Komunikasi Digital di kelas X SMK negeri 3 Singaraja dilakukan, didapatkan hasil rata-rata skor respon sebesar 68,9 yang berada pada kriteria "Sangat Praktis". Sedangkan untuk respon guru terhadap konten interaktif mata pelajaran Simulasi dan Komunikasi Digital di kelas X SMK negeri 3 Singaraja memperoleh memperoleh rata-rata nilai sebesar 47. Jika dikonversikan ke dalam tabel penggolongan respon guru maka nilai rata-rata tersebut masuk ke dalam kriteria "Sangat Praktis".

Adapun saran bagi pengembang konten interaktif selanjutnya agar dapat melakukan penyempurnaan dan juga penambahan fitur-fitur pada media pengemas konten interaktif yang dikembangkan sendiri diluar pengembangan konten interaktif. Seperti pengembangan media video pembelajaran yang menunjang pembelajaran menggunakan konten interaktif mata pelajaran Simulasi dan Komunikasi Digital. Serta bagi pengembangan konten interaktif mata pelajaran Simulasi dan Komunikasi Digital berstrategi Blended Learning di kelas X SMK Negeri 3 Singaraja ini belum sampai ke tahap pengukuran hasil belajar dari peserta didik secara lebih detail. Pelaksanaan pengukuran hasil belajar hanya dilakukan secara ringkas melaui pelaksanaan pretest dan posttest yang memperoleh hasil terkait dengan efetivitas konten interaktif. Oleh karena itu, perlu dilakukannya pengkajian secara lebih lanjut mengenai efektivitas penggunaan konten interaktif yang berkaitan dengan pengukuran hasil pembelajaran peserta didik secara lebih detail melalui penelitian eksperimen.

\section{REFRENSI}

[1] Arsyad, A. (2006). Media Pembelajaran. Jakarta: PT. Rajagrafindo Persada

[2] Asyar, R. (2012). Kreatif Mengembangkan Media Pembelajran. Jakarta: Gaung Persada Press

[3] Suyasa, P. W. A., Divayana, D. G. H., \& Kristiantari, M. R. (2021). The effect of digital books based on kvisoft flipbook maker on student learning outcomes. Journal of Physics:
Conference Series, 1810(1). https://doi.org/10.1088/1742$6596 / 1810 / 1 / 012046$

[4] Graham, C.R. (2005). Blended learning system: Definition, current trends and future direction. In: Bonk, C.J., Graham, C.R. (eds.) Handbook of Blended learning: Global Perspectives, Local Designs. San Francisco: Pfeiffer.

[5] Arsyad, A. (2002). Media Pembelajaran. Jakarta: Raja Grafindo Persada.

[6] Sadiman, A. (2002). Media Pendidikan dan Proses Belajar Mengajar, Pengertian Pengembangan dan Pemanfaatannya, Jakarta: Raja Grafindo Persada

[7] Driscoll, M. (2002). Blended Learning: Let's Get beyond the Hype. IBM Global Services. Http://.sibatik.kemdikbud.go.id , pengantar $>$ pdf $>$ pengantar 3

[8] Kurniawan, M. (2016). Penggunaan Modle "Flearn" Sebagai Learning Management System (Lms) Di Universitas Kristen Satya Wacana. 677-686.

[9] Munir. (2013). Multimedia Konsep dan Aplikasi dalam Pendidikan. Bandung: Alfabeta

[10] Dhika, H., Destiawati, F., Surajiyo, S., \& Jaya, M. (2020). Implementasi Learning Management System Dalam Media Pembelajaran Menggunakan Moodle. Prosiding Seminar Nasional Riset Information Science (Senaris), 2(0), 228-234. Http://Tunasbangsa.Ac.Id/Seminar/Index.Php/Senaris/Article/Vi ew/166

[11] Tegeh, I. M., dan I. M. Kirna (2010). Metode Penelitian Pengembangan Pendidikan. Singaraja: Undiksha

[12] Sugiyono. (2017). Metode Penelitian Pendidikan. Bandung: Alvabeta

[13] Tegeh, I. M, et al. (2014). Model Penelitian Pengembangan. Cetakan Pertama. Graha Ilmu: Yogyakarta

[14] Candiasa, I. M. (2011). Pengujian Instrumen Penelitian disertai Aplikasi ITEMAN dan BIGSTEPS. Singaraja: Undiksha Press

[15] Agustini, K., Santyadiputra, G. S., \& Sugihartini, N. (2020). Visualizing The Stages of The Educational Research Methodology Into Animation Infographics For Vocational Students. Jurnal Pendidikan Vokasi, 9(3), 318328.Https://journal.uny.ac.id/index.php/jpv/article/view/22017/1 3109.

[16] Carman, J. M. (2002). Blended Learning Design: Five KeyIngredients.Blended2010.pbworks.com/f/Carman.pdf

[17] Arthawan, I. P. A. Y., Suyasa, P. W. A., \& Wahyuni, D. S. (2020). Pengembangan Konten Pembelajaran dengan Model Blended Learning Pada Mata Pelajaran Informatika. Kumpulan Artikel Mahasiswa Pendidikan Teknik Informatika (KARMAPATI), 9, 172-184. 